\title{
MANAJEMEN PEMBENIHAN IKAN LELE SANGKURIANG (Clarias $s p$ ) DI DESA KEDUNGLOSARI KECAMATAN TEMBELANG KABUPATEN JOMBANG
}

\author{
Endah Sih Prihatini* \\ *Fakultas Perikanan Universitas Islam Lamongan \\ Jl. Veteran No. 53 A Lamongan Phone /Fax 0322_324706
}

\begin{abstract}
ABSTRAK
Penelitian ini bertujuan untuk mengetahui manajemen pembenihan ikan lele Sangkuriang dan mengetahui faktor pendukung serta penghambat usaha pembenihan ikan lele Sangakuriang. Penelitian ini dilaksanakan di desa Kedunglosari Kecamatan Tembelang Kabupaten Jombang dengan tiga responden usaha pembenihan ikan lele Sangkuriang. Hasil penelitian didapatkan bahwa manajemen pembenihan ikan lele Sangkuriang dilihat dari aspek kelembagaan, aspek tehnik dan aspek pemasaran cukup baik. Aspek finansial diperoleh nilai R/C sebesar 1,87. Faktor pendukung usaha pembenihan ini adalah sumber air yang cukup, lokasi dekat dengan jalan raya. Faktor penghambatnya adalah perbedaan suhu tinggi pada siang dan malam hari, banyak benih stress dan mati. Faktor kritis kematian benih pada saat pergantian pakan benih dari kuning telur, dengan cacing sutra atau pellet berprotein tinggi.
\end{abstract}

Kata kunci ; ikan lele, manajemen, pembenihan

\section{PENDAHULUAN}

Ikan lele adalah ikan air tawar yang telah dibudidayakan diseluruh penduduk Indonesia khususnya pulau Jawa, mempunyai keunggulan dapat dipelihara dengan kepadatan tinggi, modal rendah, lahan sempit dengan sumber air terbatas (Saparinto, 2012) . Peningkatan produksi budidaya lele sangat mungkin karena luas lahan tersedia air tawar jumlahnya besar, teknologi budidaya telah dikuasai, sumber daya manusia tersedia, permintaan pasar akan meningkat (Ghufran $\mathrm{H}$. Kordi, 2012).

Pengembangan komoditas budidaya ikan lele tidak terlepas dari aspek budidaya. Aspek aspek dalam budidaya ikan lele adalah aspek teknis, aspek finansial, aspek pemasaran, dan aspek kelembagaan usaha.. Keberhasilan pengembangan budidaya lele disokong oleh manajemen usaha yang baik agar mendapatkan hasil produksi yang optimal (Pasaribu, 2012).

Lele sangkuriang ini merupakan hasil perbaikan genetika ikan lele yang dilakukan
(BBPAT) Balai Besar Pengembangan Air Tawar Sukabumi melakukan perkawinan induk ikan lele dumbo di Indonesia. Perkawinan induk lele dumbo di Indonesia perkawinan dilakukan antara induk betina generasi (F2) dari Afrika dan induk F2-6 betina menghasilkan generasi F2 sehingga mendapat hasil lele Sangkuriang (Sunarma, 2004).

Keberhasilan mendapatkan hasil produksi berasal dari usaha pembenihan yang baik. Pembenihan adalah salah satu usaha untuk membesarkan induk, memijahkan, menetaskan, memelihara larva atau benih sampai siap ditebar dikolam atau dijual (Suyanto dan Hernowo, 2006).

Pengembangan usaha pembenihan ikan lele sangkuriang (Clarias $s p$ ) juga dilakukan di desa Kedunglosari Kecamatan Tembelang Kabupaten Jombang. Untuk mengetahui usaha tersebut dapat diaplikasikan secara menyeluruh diseluruh daerah atau oleh karena itu perlu diketahuinya informasi manajemen 
pembenihan dan kelayakan usaha serta faktor pendukung dan penghambatnya.

\section{METODE PELAKSANAAN}

Penelitian ini dilaksanakan di desa Kedunglosari kecamatan Tembelang kabupaten Jombang pada bulan September sampai dengan Oktober 2017.

Metode yang digunakan dalam penelitian ini adalah metode diskriptif adalah menjelaskan bahwa penelitian tidak sekedar menjelaskan peristiwanya (masalahnya) tetapi mendiskripsikan bagaimana peristiwa itu bisa terjadi (Malamassam, 2009). Metode diskriptif adalah metode dalam meneliti status kelompok manusia, suatu obyek, suatu kondisi, sistem pemikirain ataupun peristiwa pada masa sekarang (Sugiyono, 2014).

\section{Teknik Pengumpulan Data}

Teknik pengumpulan data dalam penelitian dilakukan dengan antara lain partisipasi aktif, observasi dan wawancara. Partisipasi Aktif adalah turut serta dalam kegiatan (Sugiyono, 2014). Peran Aktif yang dilakukan dalam kegiatan pembenihan ini antara lain : persiapan kolam pemijahan, pemilihan induk ikan lele, pemijahan, penetasan telur, pendederan benih. Pengontrolan kualitas air, pemberian pakan benih lele, induk lele, pemanenan, pengemasan dan pemasaran.

Observasi adalah melakukan pengamatan dan pencatatan secara sistematis gejala atau fenomena yang diselidiki (Ari Kunto, 2013). Kegiatan observasi yang dilakukan dalam penelitian ini adalah kontruksi kolam terdapat sutlet dan inlet, keberhasilan pembenihan ditentukan oleh pematangan gonat pada induk, kualitas air, kondisi lokasi budidaya, kegiatan pembenihan Ikan Lele Sangkuriang.

Wawancara adalah teknik pengumpulan data dengan menggunakan tanya jawab kepada narasumber/responden (Sugiyono, 2014). Daftar pertanyaan disiapkan peneliti agar hasil yang didapat fokus apa yang ingin diketahui. Wawancara yang dilakukan antara lain aspek kelembagaan, aspek teknik, aspek pemasaran, dan aspek finansial pembenihan Ikan Lele Sangkuriang serta faktor penghambat dan faktor pendukung usaha pembenihan tersebut.

\section{Jenis dan Sumber Data}

Jenis data yang diambil dalam penelitian ini adalah data primer dan data sekunder. Data Primer adalah data yang diperoleh langsung dari sumber aslinya baik individu atau perorangan seperti hasil wawancara, atau pengisian questioner yang dilakukan peneliti (Ari Kunto, 2013). Data sekunder adalah data yang diperoleh secara tak langsung misal, data biro statistik, majalah data instansi pemerintah (Sugiyono, 2014).

\section{Metode Pengambilan Data}

Usaha pembenihan ikan lele di Desa Kedunglosari ada 3 tempat. Semua digunakan responden dalam penelitian ini. Setiap responden mempunyai kolam induk, kolam pemijahan, kolam penetasan, kolam pendederan, mempunyai sumber air bor, lokasinya dekat jalan raya, mempunyai jaringan listrik, manajemen pembenihan cukup baik, pendidikan SMA dan sarjana.

\section{Analisis Data}

Data hasil penelitian, aspek tehnik mulai dari persiapan kolam, pemeliharaan induk, pemilihan induk yang matang kelamin, pemijahan ikan lele, penetasan telur, pendederan benih, pemanenan, aspek pemasaran, analisis finansial, dijelaskan dan disimpulkan. Aspek finansial usaha pembenihan ikan lele sangkuriang bisa dilihat dari analisis kelayakan usahanya. Analisis kelayakan unit usaha dapat dilakukan dengan rumus $\mathrm{R} / \mathrm{C}$ (Revenue Cost) rasio merupakan alat analisis melihat rasio keuntungan dari perbandingan Total Revenue (T.R) dengan Total Cost (TC) (Soekartawi, 2005). Nilai R/C $>1$ berarti usaha tersebut untung, apabila $\mathrm{R} / \mathrm{C}$ $=1$, berarti usaha tersebut tidak rugi maupun untung dan apabila $\mathrm{R} / \mathrm{C}<1$, usaha tersebut rugi. Total Revenue adalah jumlah penerimaan total usaha yang didapat dari perkalian produksi dikalikan harga dan dirumuskan 
secara matematika sebagai berikut: TR $=\mathrm{P} \times \mathrm{Q}$, dimana $\mathrm{P}=$ Price (Harga), dan $\mathrm{Q}=$ Jumlah (Quantity). (Shinta, 2011). Total Cost adalah jumlah total biaya yang dikeluarkan untuk menghasilkan produksi. Rumusan secara matematika Total Cost $(\mathrm{TC})=\mathrm{FC}+\mathrm{VC}, \mathrm{FC}=$ Fixed Cost (Biaya Tetap) adalah biaya yang tidak habis digunakan dalam produksi, misal kolam, alat tanjaran, serok, pompa air dan sebagainya (Soekartawi, 2005). Pendapatan usaha pembenihan adalah selisih antara penerimaan dengan semua pengeluaran (biaya) dirumuskan secara matematika TC Pendapatan = TR - TC (Soegiarto, dkk,2005) . Variabel Cost adalah biaya yang habis digunakan dalam usaha pembenihan, misal biaya listrik, pakan, probiotik dan sebagainya.

\section{Hasil Dan Pembahasan}

Manajemen Usaha Pembenihan Ikan Lele Sangkuriang. Manajemen adalah suatu kegiatan mengerahkan tenaga, fikiran, tubuh untuk mencapai tujuan melalui pelaksanaan fungsi planning, organizing, acuiting dan controling (Firdaus, 2009), Bagan manajemen pembenihan ikan lele Sangkuriang bisa dilihat pada gambar (GB) 1 di bawah ini :

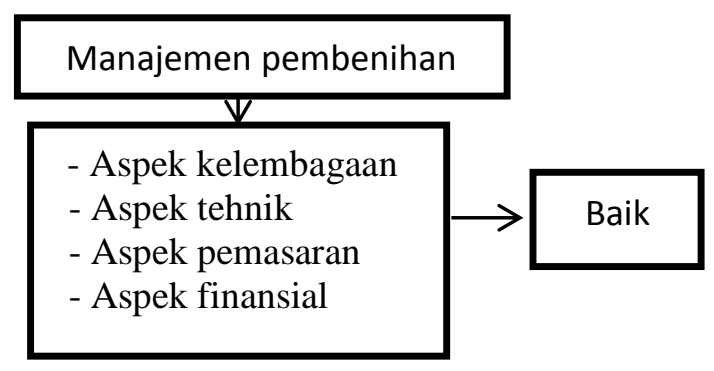

Gambar 1. Bagan manajemen pembenihan ikan lele Sangkuriang.

Keberhasilan manajemen usaha pembenihan ini akan menghasilkan produk benih yang tinggi, ditentukan antara lain adalah aspek kelembagaan, aspek tehnik, aspek pemasaran dan aspek finansial.

\section{Aspek tehnik}

Tahapan aspek teknik pembenihan ikan lele Sangkuriang bisa dilihat pada gambar (Gambar 2) di bawah ini :

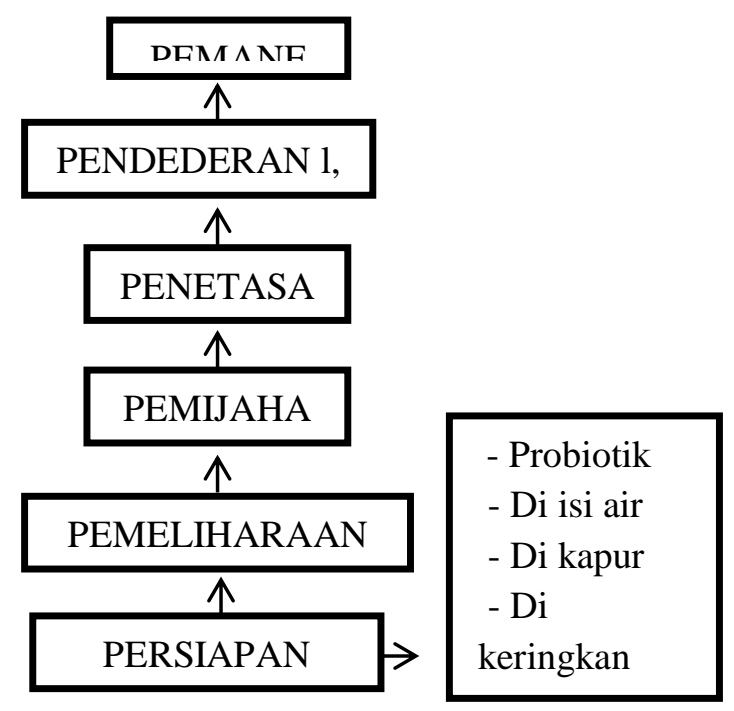

Gambar 2. Tahapan aspek teknik pembenihan ikan lele Sangkuriang.

\section{A. Pemeliharaan Induk}

Pemeliharaan induk diperlukan agar dihasilkan produksi yang baik. Keberhasilan pembenihan ditentukan faktor eksternal dan faktor internal. Faktor internal antara lain adalah induk yang telah matang kelamin perlu diberi makanan bergizi dengan pemberian pakan 3 kali sehari. Makanan induk ikan lele bisa berupa besusul, pellet, cepret. Kolam induk jantan dipisahkan dengan induk betina agar tidak terjadi perkawinan. Kualitas air kolam induk harus dijaga. Dengan mengganti seperempat air kolam, jika kelihatan keruh atau setiap seminggu sekali.

Pemberian pakan selain pellet diberi variasi kecambah, anak katak. Pemberian probiotik diberikan untuk menjaga kualitas air, menguraikan kotoran dan sisa pakan menjadi bahan yang tidak berbahaya.

Pemilihan induk yang matang kelamin diperlukan agar mendapatkan hasil benih maksimal dan kualitasnya baik. Induk lele jantan yang matang kelamin apabila diurut perutnya akan mengeluarkan sperma. Induk betina jika diurut akan mengeluarkan telur yang berwarna kuning. Sesuai pendapat (Suyanto dan Hernowo, 2006) induk lele yang telah matang kelamin, yang jantan akan mengeluarkan sperma jika diurut, sedang yang betina mengeluarkan telur yang 
berwarna kuning. Ciri lain lubang general berwarna merah pada induk jantan.

Pada usaha pembenihan ini induk yang matang kelamin dipisahkan dan dikawinkan dengan perbadingan 2:1 atau 1:1

\section{Pemijahan \& Penetasan Telur}

Sebelum digunakan untuk pemijahan kolam dibersihkan terlebih dahulu dari kotoran dengan sabun. Setelah itu dibersihkan dan diberi chlorin untuk membunuh bibit penyakit, dikeringkan dan dibiarkan selama 1 hari. Setelah itu kolam diisi air dengan ketinggian $60 \mathrm{~cm}$, diberi probiotik untuk menjaga kualitas air kolam sesuai Effendi (2003) bahwa probiotik berfungsi untuk menguraikan senyawa komplek menjadi senyawa sederhana, juga bisa menjaga kestabilan kualitas air kolam. Selama 3 hari dibiarkan agar kualitas air kolam stabil dilihat dari sifat fisika, kimia dan sifat biologi.

Kakaban diletakkan di tengah kolam pemijahan dan dikedua sisi diberi pemberat dari batu bata atau genting agar kakaban tidak terapung pada permukaan kolam dan tidak bergeser saat proses pemijahan.

Setelah itu induk jantan dan induk betina dimasukkan dalam kolam pemijahan dengan perbandingan 2:1 ialah dua induk betina, satu induk jantan biasanya dilakukan jam 10.00 Waktu Indonesia Barat (WIB). Induk yang matang kelamin pada jam 19.00-20.00 WIB melakukan pemijahan ditandai induk ikan lele berkejarkejaran. Pada jam 24.00-04.00 WIB induk ikan lele betina akan melepaskan tekurnya dan induk jantan akan mengeluarkan sperma dan akan membuahi telur-telur yang melekat pada kakaban.Setelah 24 jam atau maksimal 3 hari, telur yang ada di kolam akan menetas. Setelah terjadi pemijahan induk lele dipindahkan ke kolam induk agar induk lele tidak memakan telur ikan lele atau benih yang sudah ditetaskan (Suyanto dan Hernowo ,2006)

Setelah terjadi penetasan telur menjadi benih, maka kakaban diambil atau dikeluarkan, dicuci sehingga terbebas dari kotoran maupun sisa penetasan telur. Pemberian pakan pada benih lele setelah lima hari, karena sebelum berumur lima hari, benih masih mempunyai cadangan kuning telur dari tubuhnya sesuai Pamuntjak (2010) setelah lima hari benih hasil penetasan telur, harus diberi pakan berupa pellet, cacing sutra, yang mempunyai protein tinggi.

\section{Pendederan}

Saat pendederan benih, persiapan kolam sama seperti kolam pemijahan antara lain pembenihan kolam, pemberian khlorin untuk membunuh bibit penyakit, kolam dikeringkan, satu hari dan diisi air dengan ketinggian $60 \mathrm{~cm}$. Pemberian probiotik dilakukan untuk menjaga kualitas air. Benih berumur 10 hari dimasukkan ke kolam pendederan, pergantian air diperlukan untuk menjaga kualitas air tetap baik. Pemberian pakan benih lele dilakukan 3 kali sehari yaitu jam 08.00 WIB, jam 12.00 WIB dan jam 16.00 WIB. Pakan yang diberikan berupa cacing sutra, pellet dengan protein $45 \%$ pada usia lebih dari 5 sampai dengan 50 hari. Pengukuran kualitas air dilakukan setiap hari untuk mengetahui kondisi air pemeliharaan ikan lele antara lain suhu : 25-28 ${ }^{\circ} \mathrm{C}$, pH:7-8, oksigen terlarut: 4-5 ppm, $\mathrm{NH}_{3}$ : 0,01-0,1 ppm sesuai dengan Effendi (2003) bahwa kualitas air usaha pembenihan ikan lele yang layak adalah suhu 26,5-28, $\mathrm{pH}$ antara 6,5-8, oksigen terlarut antara 3-5 ppm. $\mathrm{NH}_{3} \rightarrow 0,01-0,1 \mathrm{ppm}$. Usaha pembenihan ikan lele Sangkuriang, pada kolam pemijahan dan kolam pendederan diberi penutup fiber yang permanen untuk menjaga suhu agar tidak terlalu panas saat kena matahari dan suhu rendah saat malam hari.

Pemberian probiotik pada kolam pendederan untuk menguraikan sisa pakan, sisa metabolisme sehingga menjadi pupuk alami sebagai tumbuhnya plankton. Penggradingan dilakukan untuk mencegah terjadinya kanibalisme antar benih dengan ukuran 1-2 $\mathrm{cm}, 2-3 \mathrm{~cm}$ dan $3-5 \mathrm{~cm}$ dengan menggunakan bak seleksi, tanjaran, seser besar dan seser kecil. Kolam pendederan I dilakukan penggradingan sampai umur 14-20 hari dengan bak seleksi 1 diameter lubang $5 \mathrm{~mm}$, ukuran benih 1-2 cm, kepadatan kolam $4.800 \mathrm{ekor} / \mathrm{m}^{2}$. Kolam pendederan II dilakukan 
penggradingan pada umur 30 hari dengan bak seleksi ukuran lubang $8 \mathrm{~mm}$, ukuran benih $2-3 \mathrm{~cm}$, kepadatan kolam 1.000-2.500 ekor $/ \mathrm{m}^{2}$.Kolam pendederan III dilakukan penggradian pada umur 50 hari, dengan bak seleksi ukuran lubang $12 \mathrm{~mm}$, ukuran benih 3-5 $\mathrm{cm}$.

\section{Pemanenan}

Pemanenan dilakukan pada saat benih berukuran 1-2 $\mathrm{cm}$. Biasanya berumur 3 minggu sampai dengan benih berukuran $3-5 \mathrm{~cm}$ biasanya berumur 50 hari. Pemanenan dilakukan dengan mengurangi air kolam sehingga ketinggian air kolam $20 \mathrm{~cm}$. Kolam penampungan disiapkan dengan diisi air setinggi $40 \mathrm{~cm}$. Tanjaran dipasang membentang dengan ketinggian 20-30 cm. Tanjaran diikat dengan tali rafia pada kolam penampungan yang dilengkapi dengan bambu. Benih diseser secara hati-hati dimasukkan ke tanjaran. Benih digrading dengan saringan ukuran $3-5 \mathrm{~cm}$. Benih ditampung dalam bejana plastik $1 / 3$ bagian. Benih dihitung dan dimasukkan dalam wadah siap diangkut.

\section{Aspek Pemasaran}

Konsumen benih lele biasanya langsung ke tempat usaha pembenihan. Komunikasi pemasaran dilakukan oleh pemilik usaha lewat telepon.

Konsumen benih lele ini berasal dari wilayah Jombang, Lamongan, Kediri, Mojokerto dan lain-lain. Proses pembayaran dilakukan secara tunai.

\section{Aspek Finansial Usaha Pembenihan Ikan Lele}

Biaya usaha pembenihan ikan lele Sangkuriang terdiri dari rata-rata biaya tetapn dan biaya variabel yang terlihat pada tabel 1 ,

Tabel 1. Total biaya rata- rata yang dikeluarkan usaha pembenihan ikan lele Sangkuriang

\begin{tabular}{ccr}
\hline No & Jenis Biaya & \multicolumn{1}{c}{ Jumlah } \\
\hline 1. & Biaya Tetap & 39.834 .833 \\
2. & Biaya Variabel & 39.144 .000 \\
\hline & Jumlah & 78.978 .833
\end{tabular}

Sumber : Data primer diolah, 2018
Penerimaan usaha pembenihan ikan lele berupa produksi benih dengan ukuran $1-2 \mathrm{~cm}$, $2-3 \mathrm{~cm}$, dan $3-5 \mathrm{~cm}$ untuk lebih jelasnya rata-rata penerimaan usaha pembenihan ikan lele bisa dilihat pada tabel berikut.

Tabel 2. Rata- rata penerimaan usaha pembenihan ikan lele Sangkuriang.

\begin{tabular}{|c|c|c|c|c|}
\hline No & $\begin{array}{l}\text { Ukuran } \\
\text { Benih }\end{array}$ & $\begin{array}{c}\text { Hasil } \\
\text { Produksi } \\
\text { (ekor) }\end{array}$ & $\begin{array}{c}\text { Harga } \\
\text { (Rupiah) }\end{array}$ & Jumlah \\
\hline 1. & $1-2 \mathrm{~cm}$ & 1.200 .000 & 50 & 60.000 .000 \\
\hline 2. & $2-3 \mathrm{~cm}$ & 800.000 & 70 & 56.000 .000 \\
\hline 3. & $3-5 \mathrm{~cm}$ & 320.000 & 100 & 32.000 .000 \\
\hline
\end{tabular}

Sumber : Data primer diolah, 2018

Pendapatan usaha pembenihan bisa dihitung dari selisih total penerimaan dengan total biaya. Rata-rata pendapatan usaha pembenihan ini adalah Rp. 69.021.167. Untuk lebih jelas bisa dilihat pada tabel 3 mempunyai nilai $\mathrm{R} / \mathrm{C}$ lebih dari 1 berarti usaha tersebut layak diusahakan.

\begin{tabular}{|c|c|c|}
\hline No & Uraian & Nilai (Rp) \\
\hline 1. & Penerimaan (TR) & 148.000 .000 \\
\hline 2. & Total Biaya (TC) & 78.978 .833 \\
\hline 3. & $\mathrm{TR}-\mathrm{TC}$ & 69.021 .167 \\
\hline
\end{tabular}

Sumber : Data primer diolah ,2018

Faktor pendukung dan faktor penghambat usaha pembenihan ikan lele Sangkuriang.

Faktor pendukung usaha pembenihan ini antara lain adalah pemilik berpendidikan SMA dan sarjana pengalamannya cukup banyak dan mau belajar untuk mengembangkan usahanya. Potensi sumber air di Jombang yang kualitasnya bagus memungkinkan untuk bisa dikembangkan usaha pembenihan lebih banyak. Desa Kedunglosari adalah daerah yang cukup strategis, dekat dengan kota, jalannya beraspal, mudah dikenal oleh masyarakat. Pasarnya cukup mudah, benih yang dihasilkan usaha pembenihan ini pemasarannya lancar. 
Faktor penghambat dalam usaha pembenihan ini adalah cuaca, suhu yang terlalu panas pada saat pagi hari dan pada saat malam hari suhu rendah. Hal itu sudah diansipasi oleh pemilik dengan pemberian penutup fiber pada kolamkolam pemijahan maupun pendederan. Kualitas air selalu diamati dan diukur untuk menjaga pengelolaan pembenihan pemberian probiotik pada kolam pembenihan juga dilakukan, tetapi pada saat tertentu hasil pembenihan jika tidak seperti yang diharapkan. Faktor kritis pembenihan pada saat telur sudah menetas jadi benih, setelah hilangnya kuning telur, yang harus diberikan pakan alami berupa cacing sutra terkadang cacing sutra itu tidak ada, diganti pellet. Hal itu sering terjadi kematian benih yang tinggi, pembenihan ikan lele perlu diberi pakan dengan protein tinggi agar pertumbuhan dan kelangsungan benih lele baik dan tinggi.

\section{KESIMPULAN DAN SARAN}

Kesimpulan dari penelitian diatas :

1. Manajemen usaha pembenihan Ikan lele Sangkuriang ini baik aspek teknik meliputi persiapan media kolam, pemeliharaan induk, pemijahan penetasan telur, pendederan, pemanenan, aspek kelembagaan dan aspek pemasaran.

2. Analisis finansial/kelayakan diperoleh hasil $\mathrm{R} / \mathrm{C}: 1,87$ artinya usaha pembenihan ini layak diusahakan. Pendukung usaha pembenihan ini antara lain adalah, pemiliknya mempunyai pengetahuan yang cukup, sumber airnya yang baik dan jumlahnya banyak, lokasinya strategis karena mudah dikenal masyarakat, pemasarannya mudah. Hambatan usaha pembenihan ikan lele adalah faktor cuaca terutama perbedaan suhu pada waktu siang dan malam, faktor pergantian pakan dari kuning telur ke pakan luar misal pellet karena keterbatasan cacing sutra. Biasanya banyak menimbulkan kematian.
Saran :

1. Dengan adanya usaha pembenihan ini diharapkan masyarakat mau belajar untuk mengembangkan usaha pembenihan yang nantinya bisa menciptakan lapangan kerja

2. Masyarakat diharapkan selalu berlatih/belajar dalam usaha pembenihan untuk menghadapi tantangan/masalah sehingga bisa menyelesaikan, karena setiap saat masalah yang dihadapi tidak sama.

\section{DAFTAR PUSTAKA}

Ari Kunto, 2013, Prosedur Penelitian, Suatu Pendekatan Praktik Rineka. Jakarta.

Effendi, H, 2003 Telaah Kualitas Air Bagi Pengolahan Sumberdaya dan Lingkungan Perairan, Kanisius Yogyakarta

Firdaus. M.2009, Manajemen Agribisnis, Bumi Aksoro, Jakarta

Ghufran M.H. Kordi ,2012, Pembesaran Lele Unggul Lily Publisher, Yogyakarta

Malamassam, 2009, Metodologi Penelitian Ekonomi, Yayasan Agro Ekonomika, Yogyakarta

Pamunjtak, W 2010 Panduan Budidaya Lele. Pustaka Araska Media Utama. Yogyakarta

Pasaribu AM. 2012 Kewirausahaan Berbasis Agribisnis C.V Andi offset Yogyakarta

Saparinto C, 2012 Panduan Lengkap Bisnis dan Budidaya Lele Unggul. Lily publisher. Yogyakarta

Shinta, 2011, Ilmu Usaha Tani. Universitas Brawijaya Press. Malang.

Soekartawi, 2005, Agribisnis, Teori, dan Aplikasinya. Grafindo Persada Jakarta

Sugiarto, Herlambang, T.Brastoro, Sudjana.R. Kelana, S, 2005. Ekonomi Mikro. Sebuah Kajian Komprehensif. Penerbit PT Gramedia Pustaka Utama. Jakarta.

Sugiyono, 2014 Metode Penelitian Kuantitatif dan Kualitatif dan R\&H. Alfabeta. Jakarta

Sunarma A, 2004 Peningkatan Produktivitas Usaha Lele Sangkuriang http;//wwwindoorcomunityfileswordpres. com.pdf diakses 17 april 2014 